This is an electronic version of an article published as: Beese, W.J. \& Arnott, J.T. (1999). Montane Alternative Silvicultural Systems (MASS): Establishing and managing a multidisciplinary, multi-partner research site. The Forestry Chronicle, 75(3), 413-416.

The Forestry Chronicle is available online at: http://pubs.cif-ifc.org/journal/tfc and this article is available at: http://pubs.cif-ifc.org/doi/pdf/10.5558/tfc75413-3. 


\title{
Montane Alternative Silvicultural Systems (MASS): Establishing and managing a multi-disciplinary, multi-partner research site
}

\author{
by W.J. Beese ${ }^{1}$ and J.T. Arnott ${ }^{2}$
}

The Montane Alternative Silvicultural Systems (MASS) study was established on Vancouver Island, B.C. to develop operationally feasible and ecologically sustainable silvicultural systems in old-growth forests. The project addresses regeneration, biodiversity and aesthetic concerns over clearcutting at high elevations. Over twenty integrated studies are examining the biological and economic consequences of shelterwood, small patch clearcut, dispersed green tree retention and clearcut alternatives. Planning and preharvest studies began two years before the 1993 harvesting. The Forest Engineering Research Institute of Canada (FERIC) documented the cost and feasibility of harvesting. Post-harvest studies have been underway for five years with funding by the Canada-B.C. Forest Resource Development Agreement (FRDA II), Forest Renewal BC (FRBC), Industry Canada and project cooperators. There are numerous challenges associated with establishing and managing a multi-disciplinary, long-term research site with multiple partners. This paper discusses the administrative aspects of integrated research based on our experience with the MASS project.

Key words: research cooperative, silvicultural systems, oldgrowth forests
L'etude sur les systemes sylvicoles alternatifs en montagne (MASS) a ete entreprise sur l'ile de Vancouver, C.-B. afin de developper des systemes realisables en terme d'operation et ecologiquement durable dans les vieilles forets. Le projet touche les questions se rapportant a la regeneration, la biodiversite et l'esthetique par rapport a la coupe a blanc a haute altitude. Plus de 20 etudes integrees etudient les consequences biologiques et economiques des coupes progressives, des coupes a blanc par trouee, de la retention d'arbres verts par bouquets disperses et des alternatives a la coupe a blanc. La planification et les etudes pre-recolte ont debute deux ans avant la recolte de 1993. L'Institut canadien de recherches en genie forestier (FERIC) a etabli le cout et la faisabilite de la recolte. Les etudes post-recolte sont en cours depuis cinq ans suite au financement par les Ententes de developpement des ressources forestieres Canada-C.B. (FRDA II), Forest Renewal BC (FRBC), Industrie Canada et par des collaborateurs au projet. Plusieurs defis sont associes a la mise en place et la gestion d'une station de recherche a long terme comportant plusieurs partenaires. Cet expose discute des aspects administratifs de la recherche integree selon notre experience du projet MASS.

Mots-cles: recherche cooperative, regimes sylvicoles, vieilles forets

\section{Introduction}

Forest managers are challenged to adapt traditional silvicultural systems and create new approaches to meet a greater spectrum of social and resource values. Concerns over the impacts of clearcutting on high elevation reforestation success, wildlife habitat, biological diversity and visual aesthetics led to the formation of a research cooperative. The Montane Alternative Silvicultural Systems (MASS) project was created to examine the biological and economic consequences of alternative silvicultural systems for high elevation forests on Vancouver Island, British Columbia. The MASS partnership is a multi-agency research effort between MacMillan Bloedel (MB), the Canadian Forest Service (CFS), the Forest Engineering Research Institute of Canada (FERIC), the University of British Columbia, the University of Victoria and the BC Ministry of Forests.

A recent paper summarizes the conclusions from the operational aspects of the study and reviews some early results from studies of the biological impacts (Arnott and Beese 1997). This paper discusses what we have learned over the past seven years,

${ }^{1}$ Sustainable Forestry Division, MacMillan Bloedel Limited, 65 Front St., Nanaimo, B.C. V9R 5H9. E-mail: wj.beese@mbltd.com

${ }^{2}$ Natural Resources Canada, Canadian Forest Service, 506 W. Burnside Rd., Victoria, B.C. V8S 4Z7. E-mail: jarnott@ pfc.forestry.ca

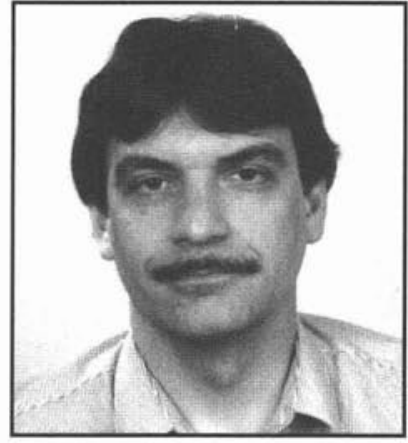

W.J. Beese

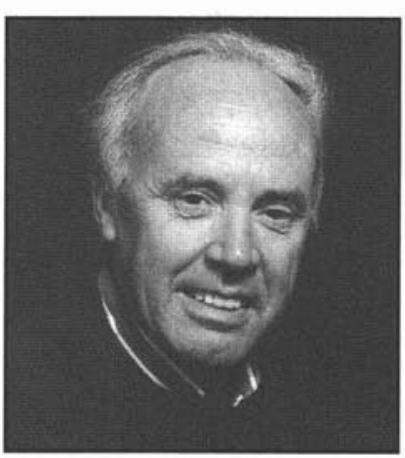

J.T. Arnott including: choosing and designing the experimental site, developing an integrated research program, promoting and funding the project, documenting research installations, managing the day-to-day operations and communicating project results. We also discuss several elements which we believe are key to a project's success.

\section{Choosing and Designing the Experimental Site}

A multi-disciplinary study examining different silvicultural systems requires a large study area. Finding a suitable area that meets the experimental criteria as well as operational feasibility is a challenge. Using personal knowledge and aerial 
photographs, the MASS planning team narrowed our search to three potential areas. The study area chosen in MacMillan Bloedel's Iron River Operation, south of Campbell River, met the following criteria established by the project team:

- at least 150 ha of contiguous old-growth forest above $700 \mathrm{~m}$ in elevation;

- accessible for research and demonstration with minimal new roads;

- topography suitable for ground-based harvesting;

- potential layout to minimize windthrow;

- relatively uniform site conditions among replicates;

- cooperation of foresters and loggers to carry out treatments; and,

- commitment to defer harvesting on an adjacent old-growth block.

The MB forest engineering staff, in consultation with researchers, designed the road system and cutblock boundaries. Pre-harvest characteristics of the study area were described in detail, including: forest cover, stand age, site series, soil physical and chemical properties, microclimate and forest birds.

The MASS study includes silvicultural systems representing a range of overstory removal: large clearcut, small patch clearcut, dispersed "green tree" retention and uniform shelterwood. The experiment includes three replicates for each treatment except the large clearcut. After dividing a 94 ha area into nine units, treatments were randomly assigned to blocks ranging in size from 8.6 to $11.5 \mathrm{ha}$. Contiguous green tree retention blocks were rejected to avoid conditions resembling the large clearcut. Adjacent to these treatments is a 69 ha clearcut and a 20 ha old growth monitoring reserve that serves as a "control." Because there are no untreated buffers between treatments, permanent monitoring plots were established within the centre of each replicate (a 1.6 hectare area), buffered by two to three tree lengths $(85 \mathrm{~m})$ of the same treatment. Plots were also established systematically within both the old growth and clearcut areas.

The experimental design had to compromise from the ideal layout by locating the old growth control and clearcut areas adjacent to the randomly assigned alternative treatments, rather than intermixed among the other treatments. We did not have enough area for three replicates of large clearcuts or old growth reserves, so we had to settle for three sampling locations within similar areas.

\section{Developing an Integrated Research Program}

An integrated project is more than a collection of independent projects at the same location. After assembling a project team to cover all major aspects, we had a series of meetings to discuss the common data requirements, potential synergies between projects and experimental layout to ensure that studies did not confound each other. We prepared a research proposal with all projects in a consistent format. Even after several years, researchers continued to discover opportunities for collaboration and data exchange. No single project could have afforded to do the treatments and build the infrastructure provided at MASS. We hope to integrate results through the FORECAST computer model calibrated with MASS data (Kimmins 1997).

\section{Promoting and Funding the Project}

Once the objectives and scope of MASS were set, project cooperators lobbied for support by their organizations before sending an integrated research proposal to potential sponsors. We developed both a biological and economic rationale to support the need for the project, and estimated the financial benefits. MASS was funded under the Canada-B.C. Forest Resource Development Agreement (FRDA II) program from 1991 through 1994. When the FRDA program ended, MASS obtained support from the Forest Renewal BC (FRBC) research program through 1999 , including several new research projects. Total funding to date for MASS by these programs and cooperating organizations is over $\$ 5.5$ million. Continual communication and extension activities help promote the study and maintain support.

\section{Documenting Research Installations}

To integrate data from various field studies and facilitate mapping, a 60-metre grid of sampling points was marked throughout each treatment with permanent metal stakes and numbered aluminum tags. Individual studies used these sampling points for sample plots, or to reference other sampling locations. Grid locations and experimental plots are being located to within 2 metres using a Global Positioning System (GPS).

Pre-harvest aerial photography was obtained in July 1992 to produce a study area map for planning and layout. Post-harvest photography (1:10 000 scale) was obtained September 1994 for preparation of digital 1:5000 base maps. The digital products allow a greater variety of map products to be produced at any scale, as well as GIS database capabilities.

Permanent photo points were established in each treatment. Photos were taken on a level tripod with a $28 \mathrm{~mm}$ wide-angle lens at $1.5 \mathrm{~m}$ above the ground, directly over metal posts. A three-photo panorama was taken from the road above each block, with photos at 300,360 and 60 degrees. A four-photo panorama was taken from the centre of the block in the four cardinal directions. Colour slides were labelled with a camera that imprints text directly on the film. Videos $(8 \mathrm{~mm}$ ) were also taken from each of the photo points.

Electronic weather stations were located throughout all treatments to monitor soil and air temperature, relative humidity, rainfall, wind and soil moisture. Weather data is maintained by Ross Benton at the Canadian Forest Service and is easily accessible to all project members through the Pacific Forestry Centre FTP site, or by request.

\section{Managing Day-to-day Operations}

The project coordinators communicate regularly with researchers and operational personnel to ensure harmonious integration of field experiments and to facilitate information exchange. Project team members meet at the Pacific Forestry Centre in spring and fall to present brief progress reports, review funding, discuss the field season and review on-going activities. Brief minutes of these meetings are distributed to the project team. Field trips are held as needed to deal with operational issues, such as planting, windfall, road maintenance, forest health and hazardous trees.

\section{Communicating Project Results}

Project results are communicated to the forest industry and a larger public audience through newsletters, journal publications, trade magazines, newspaper articles, workshops and numerous field tours. There has been tremendous interest in the study by foresters and others; consequently, numer- 
ous tours have occurred. A field tour guide is updated annually. Over 1000 people have visited the site since 1993, and over 5000 people have seen presentations on the project at local, regional and international conferences since its inception. A MASS workshop and field tour was held in June 1995 from which a proceedings of initial findings was published (Arnott et al. 1995). The collaborators are producing a growing number of publications. A description of all MASS studies and publications can be found on the project's Internet home page. ${ }^{3}$ Master lists of presentations, publications and project leaders as well as updated information and images are given on the web site. The site links with other silvicultural systems projects in B.C. (e.g., Sicamous Creek, Date Creek), as well as the web sites of project partners, including FRBC.

\section{Keys to Success}

There are several key elements necessary to ensure a successful project:

- Leadership

- Communication

- Involvement

- Commitment

- Identity

\section{Leadership}

Every project needs a champion - an individual with the dedication and vision to keep the project alive. Even though a committee may be responsible for the project, it is still essential to have someone with personal ownership. In most cases, this will be the project leader or committee chair; but sometimes an individual within the group by virtue of their enthusiasm and commitment takes this role. The leader sets a direction and leads the project team through the roadblocks such as lack of funding or conflicts among team members. The leader needs the support of their employer to be able to dedicate the time needed for project coordination - a task often underestimated. The MASS project was fortunate to have financial support from FRDA II and FRBC for coordination. We also made a successful transition from a single project leader to co-leaders when it became necessary to share the workload and responsibilities. A close working relationship and regular communication made this work. There is a danger in dual leadership, however, because responsibilities for coordination tasks may become unclear.

\section{Communication}

Any multi-partner effort requires regular communication among team members to run smoothly and successfully. Many potential conflicts can be averted through open communication. During the harvesting phase of MASS, communication with supervisors, fallers and machine operators was critical to ensure that treatments were carried out consistently between replicates and according to the objectives. The advent of e-mail made communication between the industrial, government and academic partners of MASS much easier, faster and less time-consuming than would be possible with faxes, mailings and phone calls. Manuscripts, meeting agendas, important information and data were easily distributed to

\footnotetext{
${ }^{3}$ www.pfc.cfs.nrcan.gc.ca/practices/mass/
}

the entire team. The interaction of operational foresters and scientists from different disciplines at semi-annual meetings was beneficial for testing hypotheses and gaining new insights. We sometimes discovered apparently conflicting results, and were able to gain a better understanding of ecological processes or relationships through our discussions.

\section{Involvement}

The MASS project relied upon local union forest workers to complete harvesting in a single season as part of their annual wood volume allocation. Consequently, the experimental blocks had a direct connection to the company's bottom line. Involvement of supervisors, fallers and hoe-forwarder operators a year ahead of the logging helped us achieve the cooperation and "buy-in" from workers that made the project successful. We also involved the Worker's Compensation Board (WCB) during harvest planning to keep safety the most important priority. Loggers viewed pre-marked stands to provide advice, helped with tree marking and were consulted regularly during harvesting. On-site monitoring by FERIC staff was instrumental in communicating regularly with the crews (Phillips 1996). The entire crew was given a presentation on the goals of the project and discussed safety issues with the WCB representative before logging commenced. Involvement of foresters, engineers and cooperating scientists in the objectives, experimental design and layout helped the project team balance the ideal and the practical.

\section{Commitment}

Both personal and organizational commitments are required for a successful long-term project. In most cases, the personal commitment of individual researchers to their component of the project is not an issue. Where personal engagement may falter is in dedication to the whole project, to cooperation and data sharing, and to integration of results. Scientists tend to be focussed on a narrow field of interest and are often rewarded more for their ability to publish in that particular field than for building cooperative relationships and integrating results with others for extension products. At this stage, MASS is still struggling with how to integrate our results in a single "story." A multi-partner study in coastal B.C. known as SCHIRP (Salal-Cedar-Hemlock Integrated Research Project (Prescott and Weetman 1994) provides a recent example of successful integration.

Organizational commitment beyond five years is difficult to obtain, particularly financial support. Even with approval in-principle, annual budgets are subject to cutbacks and changing priorities. As with most long-term research efforts, future funding for MASS is based on faith - we've built a good foundation, so someone will likely be willing to help continue to support it. Worthy of note is the fact that MacMillan Bloedel committed to leave a 20-ha old growth "control" area on private land for study for at least 20 years.

\section{Identity}

A strong sense of project identity can build team spirit, help attract and maintain funding support and promote extension activities. The "MASS" acronym and logo helped bring a unique identity to the project. Even such simple gestures as giving MASS hats to all the loggers, researchers and managers working on the project contributed to this sense of identity. 


\section{Conclusion}

The MASS project has created a long-term research installation where multi-disciplinary projects can be undertaken in montane coastal forests with replicated alternative silvicultural treatments. The study area has already attracted several additional studies. The experimental installation will be monitored for at least 20 years, at intervals determined by future funding arrangements among cooperators. Ideally, the project will extend to the entire forest rotation. Project results will assist development of guidelines for forest practices in montane coastal B.C. forests. MASS is part of FERNS (Forest Ecosystem Research Network of Sites), a program by the CFS, which fosters communication between long-term silvicultural research sites across Canada.

\section{References}

Arnott, J.T., W.J. Beese, A.K. Mitchell and J. Peterson (eds.). 1995.

Proceedings of Montane Alternative Silviculture Systems (MASS) workshop. June 7-8, 1995, Courtenay, B.C., Canadian Forest Service and B.C. Ministry of Forests, Victoria, B.C. FRDA Report No. 238. $122 \mathrm{pp}$.

Arnott, J.T. and W.J. Beese. 1997. Alternatives to clearcutting in B.C. coastal montane forests. For. Chron. 73(6): 670-678.

Kimmins, J.P. 1997. Forest Ecology. 2nd Ed. Prentice Hall, New Jersey. 596 pp.

Phillips, E.J. 1996. Comparing silvicultural systems in a coastal montane forest: Productivity and cost of harvesting operations. Canadian Forest Service and B.C. Ministry of Forests, Victoria, B.C., FRDA Report No. 247. 42 pp.

Prescott, C.E. and G.F. Weetman. 1994. Salal Cedar Hemlock Integrated Research Program: A Synthesis. Faculty of Forestry, Univ. of British Columbia, Vancouver, BC. 85 pp. 